Gretchen L. Hoffman — Texas Woman's University

\title{
How are Cookbooks Classified in Libraries? An Examination of LCSH and LCC
}

\begin{abstract}
There is growing interest in food and cooking in the United States, and cookbooks are published on every topic. Library standards for subject analysis must accurately represent and organize cookbooks and materials on cooking. This paper describes a research project that examined the subject of cooking in the Library of Congress Subject Headings and the Library of Congress Classification using the work of Hope Olson as a framework. It examined how the subject headings and classification numbers are constructed, how they changed over time, and how national and ethnic cuisines are treated in each standard.
\end{abstract}

\section{Introduction}

Food and cooking are popular topics in the United States. People are told to eat healthier, follow specific diets, and restrict certain ingredients. People are encouraged to make ethical and sustainable food choices by buying "local" food, joining community supported agriculture (CSA) programs, and planting gardens. Celebrity chefs, restaurants, and gourmet grocery stores tout a "foodie" lifestyle that focuses on food. People are exploring food from around the world, and American cooking is a mix of different national, ethnic, and regional cuisines. Researchers in many academic disciplines study food, and "Food Studies" programs have been developed at several universities. Numerous television programs, radio shows, and blogs talk about food and cooking. There seems to be a cookbook on every topic, for every diet, and by every celebrity chef and restaurant. Everyone, from the home cook to the professional chef to the academic researcher, is talking about food.

To facilitate access to cookbooks and materials on cooking, libraries must organize these materials well. This paper describes a research project that examines how cookbooks are treated in two widely-used standards for subject analysis in the United States: the Library of Congress Subject Headings and the Library of Congress Classification. Informed by the work of Hope Olson, this project examines how each standard treats national and ethnic groups in the United States.

\section{Research questions}

1. How are cookbook subject headings constructed in the Library of Congress

Subject Headings, and how have they changed over time?

2. How are cookbooks classified in the Library of Congress Classification, and how has the classification changed over time?

3. How are cookbooks about national and ethnic groups in the United States treated in each standard?

\section{Background}

The Library of Congress Subject Headings (LCSH) and the Library of Congress Classification (LCC) are standards that facilitate subject access in libraries. Developed at the beginning of the 20th century, they work together to collocate and organize library materials on the same subject. The Library of Congress is responsible 
for the development and maintenance of each standard. Here is a brief description of each standard.

LCSH is the most-used subject headings list in the world. The first edition, called Subject Headings used in the Dictionary Catalogues of the Library of Congress, was published between 1910 and 1914. With the eighth edition (1975), the title was changed to Library of Congress Subject Headings. It was published irregularly until the eleventh edition (1988), when it became an annual publication. The subject headings are updated weekly, and the most current headings are available in the online Library of Congress Authorities database. LCSH is a controlled vocabulary in which a main subject heading represents a topic, and sometimes topical, chronological, and form subdivisions can be added to bring out aspects of each topic. To control language, LCSH assigns one authorized form of a subject heading and includes cross-references from other possible forms of the subject. Cross-references include: Used for (UF), See (USE), See also (SA), Related term (RT), Narrower term (NT), and Broader term (BT). LCSH uses broader and narrower terms to connect headings that are related hierarchically (Chan 2005). The headings are meant to be universal and to apply to the majority of users.

LCC is a classification scheme primarily used in academic, research, and special libraries. LCC was developed by Charles Martel and James C.M. Hanson, who based it on Charles Cutter's Expansive Classification. There are 21 main subject classes based on letters of the alphabet, and each class contains several subclasses for topics within it. Each subject is represented by a series of letters and numbers. LCC is a hierarchical system that goes from general to specific categories, and it is an enumerative system that assigns a classification number to every subject that is needed in the system. Each main class in LCC is maintained and published as a separate schedule. "Class Z: Bibliography and Library Science" was the first schedule published, in 1901, and the rest of the classes were published irregularly until 1948, except for Class K, in which subclass KF (Law of the United States) was published in 1969 (Chan 1999). LCC is updated monthly, and current numbers are available in the Classification Web database.

LCSH and LCC are based on "literary warrant." This means a subject heading and classification number are created only when something has been published on a particular topic. Therefore, LCSH and LCC are not universal standards that represent knowledge. They were developed to describe materials in the Library of Congress. Today, the Library of Congress accepts suggestions and will consider additions/changes if there is literary warrant. In addition to literary warrant, LCSH and LCC can be slow to change because revisions can be costly and time consuming for libraries. Because of the slow pace of change, the standards have been criticized for not reflecting more accurate and culturally sensitive views of concepts and people. Many researchers have criticized them for showing an American, East-Coast, white, male, Christian, and Protestant bias (see e.g., Berman 1971, 1981, 2000; Fina 1993; Knowlton 2005; Marshall 1972).

Little is written about the development of the cooking subject headings in LCSH or the cooking classification numbers in LCC, and there are no studies that examine cooking subject headings or classification numbers. The biggest change in this subject happened in 2010 when the Library of Congress changed the name of the 
subject from "Cookery" to "Cooking." This was done "to modernize the subject headings treatment for cooking and cookbooks" (LC 2009, 1). Although "cookery" most accurately describes the subject, it confused users and catalogers in the United States. This is a major change in the cooking subject headings and classification.

\section{Theoretical framework}

This research project is framed by the work of Hope Olson. Olson (2000, 2001a, 2001b, 2004) contends that the search for a "universal" language in subject headings and classification standards marginalizes and excludes concepts and people that do not fit into them. This research project takes the assumptions posed by Olson $(1998,254)$ that "First, classification, like any map, is constructed by dominant cultural discourses. Second, classification, like any system, has constructed boundaries or limits that result in exclusions. Third, the construction of classification is a form of location that defines and sequences what is accepted as knowledge, thus marginalizing as well as excluding." LCSH and LCC are socially constructed, and through the naming process, choices are made that construct subjects. Olson $(2002,6)$ states, "Naming information...is not simply representation of information, but is also the construction of that information." Although each standard reflects published materials, certain decisions have been made about what to include and what to exclude in each standard. A critical examination can find ways to make each standard more "permeable" and to find ways to include marginalized and excluded viewpoints and concepts. One way to make the standards more permeable is through the use of nonhierarchical relationships, like related terms (Olson 2007).

\section{Methodology}

The research was performed by examining the cooking subject headings in each edition of LCSH and the cooking classification numbers in each edition of LCC. For LCSH, the cooking subject headings in the first edition (1910/1914) through the 34th edition (2012) were examined (except the twelfth edition, 1989), as well as the most current subject headings in the Library of Congress Authorities database. For LCC, the first edition (1910) through the 2010 edition [the tenth edition] of the TX subclass in the "Class T: Technology" schedule were examined (except the fifth edition, 1971), as well as the most current numbers in the Classification Web database. Some cookbooks are classed in the RM subclass of the "Class R: Medicine" schedule, but due to the size of the research project, RM was not examined.

Various topics were examined in LCSH and LCC. First, the entire cooking area was examined to understand how cooking was originally constructed in each standard and how the structure changed over time. Then, "Cookery, American" in each standard was examined to understand how American cooking is structured, how ethnic groups in America are treated in each standard, and to look for potential issues that should be addressed. Finally, three subject headings/classification numbers were identified for further research: "African American cooking," "Mexican American cooking," and "Indian cooking." They were examined in each edition of LCSH and LCC to understand how/when they were constructed and how they changed over time.

There are some limitations to this project. Exact dates of some subject heading and classification additions/changes were not found. This research project also cannot 
give reasons for the construction of the cooking subject headings and classification numbers. Finally, it does not address cookbooks for specific diseases or diets that are classed in the RM subclass. This is a large area that needs further study.

This is the first research project that looks at cooking subject headings and classification numbers in LCSH and LCC. There have been several studies about how LCSH and LCC treat a variety of subjects, and current studies include Christensen (2008), Drabinski (2013), and Julien et al. (2012).

\section{Findings/Discussion}

The structure of the cooking subject headings in LCSH and classification numbers in LCC was developed in the early 20th century, and research reveals the structure has not changed significantly over time. Although more subject headings and classification numbers have been added, the overall structure still reflects an early 20th century understanding of cooking.

Library of Congress Subject Headings. There are seven types of subject headings used for cooking and cookbooks today, and they are constructed in various ways:

1. "Cookbooks" for works about cooking.

2. "Cookbooks" as a genre/form or a topical heading for works about cookbooks.

3. National and ethnic cuisines and styles of cooking, e.g., Cooking, Thai; Cooking, Basque;

Cooking, Austrian - Viennese style

4. Specific ingredients or foods, e.g., Cooking (Chocolate);

5. Recipes for special types of diets, e.g., Cookery for the sick; Cancer - Diet therapy - Recipes; Low-fat diet - Recipes;

6. Recipes associated with specific institutions or organizations, e.g., Lady \& Sons (Restaurant);

7. Other special aspects of cooking, e.g., Desserts; Baking; Breakfasts

(Subject Headings Manual 2008).

With the exception of the institution and genre headings, these types of subject headings have remained constant. They are constructed in the same way as the first edition of LCSH. See Table 1.

Table 1. Cooking subject headings in LCSH, 1910/1914 and 2013

\begin{tabular}{|l|l|}
\hline \multicolumn{1}{|c|}{$\mathbf{1 9 1 0 / 1 9 1 4}$} & \multicolumn{1}{c|}{$\mathbf{2 0 1 3}$} \\
\hline Cookery & Cooking \\
\hline Cookery, French & Cooking, French \\
\hline Cookery (Eggs) & Cooking (Eggs) \\
\hline Cookery for the sick & Cooking for the sick \\
\hline Baking & Baking \\
\hline
\end{tabular}

These are identical subject headings, except for the change from cookery to cooking. Although subject headings have been added over the years for more national and ethnic cuisines, more ingredients, more special diets, etc., the overall structure of the headings has not changed in 100 years.

Results also show there is a subject heading for most national and ethnic cuisines in the world. Some are subdivided by regional style, e.g., Cooking, Italian-Sicilian style. These headings are warranted, because cookbooks can focus on a particular type of cuisine. However, cookbooks do not always fit neatly into one national or ethnic category. This is especially problematic in American cooking. The main subject heading is "Cooking, American" and there are subject headings for 
specific regional styles of cooking (Cooking, American -- California style; Cooking, American -- Southern style) and cookbooks about a particular state (Cooking - Texas). Cookbooks about national ethnic groups in the United States, however, are assigned the heading for the national cuisine. For example, an Italian American cookbook would be assigned the subject heading "Cooking, Italian." This is problematic because it excludes national/ethnic cuisines from American cooking, even if the recipes are distinctly American. There are additional problems with three subject headings for cookbooks about ethnic groups in the United States: African American cooking (Soul food cooking), Mexican American cooking (Tex-Mex cooking), and Indian cooking.

African American cooking (Soul food cooking). The subject heading "African American cooking" has changed several times since "Cookery, Negro" was first published in 1957. The heading changed to "Cookery, Afro-American" in fall 1975, then flipped to "Afro-American cookery" in fall 1991. It was changed to "African American cookery" in 2000, and then to "African American cooking" in 2010. One problem with the heading is its direct order. It is placed with other African American subject headings, but it is excluded from all other national/ethnic cooking subject headings. Another problem is the cross-reference "Soul food cooking," first published in LCSH in 1980. "Soul food" is an expression popularized in the 1960s (based on "soul music") that describes African American cuisine in the southern United States (Oxford 2005). Instead of getting its own subject heading, however, "Soul food cooking" was added as a reference to "African American cooking." If a cookbook is about soul food, the heading "African American cooking" must be used on the bibliographic record. This makes "Soul food cooking" and "African American cooking" equivalent headings. Although soul food is African American cooking, not all African American cooking may be soul food. Also, because it is just a see reference, there is no way to show that soul food cooking is related to southern cooking.

Mexican American cooking (Tex-Mex cooking). There is a similar problem with "Mexican American cooking" and its cross-reference "Tex-Mex cooking." "Mexican American cooking" was first published in 1980 as "Cookery, Mexican American." It was flipped in fall 1991 to "Mexican American cookery" and changed to "Mexican American cooking" in 2010. The direct order of this heading is problematic, because like African American cooking, it excludes the heading from all other national/ethnic cuisines. Also, this heading is an exception to the practice of assigning national subject headings to cookbooks about national ethnic groups in the United States. Following the pattern, Mexican American cookbooks should be assigned the subject heading "Cooking, Mexican." Another problem is the cross-reference "TexMex cooking." Tex-Mex is a hybrid style of cooking that blends cuisines from Mexico, Texas, and Northeast New Mexico, and it is related to southwestern cooking (Oxford 2005). "Tex-Mex cooking" is a reference on the subject heading "Mexican American cooking" and was first published in 1989 or 1990. If a cookbook is about Tex-Mex cooking, then "Mexican American cooking" must be added to the bibliographic record. This makes "Tex-Mex cooking" equivalent to "Mexican American cooking," but not all Tex-Mex is Mexican American cooking, and not all Mexican American cooking is Tex-Mex. Also, because "Tex-Mex cooking" is just a reference, there is no way to show that Tex-Mex cooking is related to cooking in Texas, New Mexico, or the southwest. 
Indian cooking. Another problematic heading is "Indian cooking." It refers to the cuisine of Native Americans in the Western Hemisphere (North America, Mexico, Central America, West Indies, and South America). It was first published in 1980 as "Cookery, Indian," flipped in summer 1994 to "Indian cookery," and changed to "Indian cooking" in 2010. Like "African American cooking" and "Mexican American cooking," a problem with "Indian cooking" is the direct order of the heading, which excludes it from all other national and ethnic cuisines. Another problem is that although LC has established "Indians" to cover all Native Americans in the Western Hemisphere, the term may not be culturally sensitive. In addition, "Indian cooking" confuses many catalogers who think it refers to the cuisine of India. It is assigned to cookbooks about India because colloquially "Indian cooking" means cooking from India (the correct heading is "Cooking, Indic"). It is a confusing heading.

Library of Congress Classification. LCC follows LCSH, and the subject of cooking is classed in two areas: 1. General cooking classified in the TX: Home Economics subclass of the "Class T: Technology" schedule; and, 2. Cooking for specific diets or diseases, which is classified in the RM: Therapeutics and Pharmacology subclass of the "Class R: Medicine" schedule. This research project focuses on the TX subclass, and research reveals that the structure of the subclass has remained fairly constant since it was first published in 1910. See Table 2.

Table 2. Library of Congress Classification TX Subclass, 1910 and 2013

\begin{tabular}{|l|l|}
\hline \multicolumn{1}{|c|}{ TX1-965: Domestic Science } & \multicolumn{1}{c|}{ TX1-1110: Home Economics } \\
\hline $\begin{array}{l}\text { TX301-339:The house (Including arrangement, care, } \\
\text { servants) }\end{array}$ & $\begin{array}{l}\text { TX301-339: The house (Including arrangement, } \\
\text { care, servants) }\end{array}$ \\
\hline TX341-641:Foods and food supply & TX341-641: Nutrition. Foods and food supply \\
\hline TX651-837: Cookery & TX642-840: Cooking \\
\hline TX851-885: Dining-room service & TX851-885: Dining-room service \\
\hline $\begin{array}{l}\text { TX901-931: Hotels, clubs, restaurants, etc. Caterers } \\
\text { and catering }\end{array}$ & $\begin{array}{l}\text { TX901-946.5: Hospitality industry. Hotels, clubs, } \\
\text { restaurants, etc. Food service }\end{array}$ \\
\hline TX950-951: Bartenders, Saloon-keepers, etc. & TX950-953: Taverns, barrooms, saloons \\
\hline $\begin{array}{l}\text { TX957-958: Apartment-house service } \\
\text { TX961-965: Cooperative housekeeping }\end{array}$ & TX955-985: Building operation and housekeeping \\
\hline & TX1100-1105: Mobile home living \\
\hline & TX1110: Recreational vehicle living \\
\hline
\end{tabular}

Although there have been some changes to the numbers, the overall structure still reflects an early 20th century understanding of the subject. The TX subclass today does not use all available numbers. Everything on home economics is classified between 1 and 1110. There is room for growth between TX1111 and TX9999, but everything has been classified closely together at the top of the classification. Cooking has only 199 numbers; this is not enough to reflect the growing interest in food and cooking today.

Similar to LCSH, the cooking area of LCC is divided between national/ethnic cuisines, ingredients, and cooking processes. For national and ethnic cuisines, all cookbooks published from 1800 to the present are classified between 714 and 725, and only a few nations are given specific numbers. This means only twelve main numbers represent the cuisines of the world. Nations/ethnicities in North America and most of Western Europe have numbers, but Latin America is pushed into TX716, and the 
Middle East, Australia, and Africa are thrown together at TX725. The current classification does not reflect all national and ethnic cuisines in the world.

For American cooking, LCC follows LCSH in that cookbooks about national ethnic groups in the United States are classed with the nation. For example, an Italian American cookbook will be given the subject heading "Cooking, Italian" and will be classed at TX723 for Italian cookbooks. Like LCSH, this means that national ethnic groups in the United States are excluded from the American cooking category, even if the cookbooks are distinctly American. Following LCSH, American cooking is divided into regional styles of cooking, which are classed at TX715.2 and a cutter number is added for a particular region. For example, Louisiana style cooking is at TX715.2.L68. American cookbooks not about a particular region are classed together at TX715, the general number for American cooking, and there are thousands of American cookbooks classed at TX715. The LC catalog alone lists over 9,000 titles at TX715. Because the classification structure favors regional styles of American cooking, it cannot accommodate ethnic groups in the United States that cannot be reduced to a particular region. This is an issue for African American cooking, Mexican American cooking, and Indian cooking.

African American cooking (Soul food cooking). African American cooking is classed under American cooking at TX715. This is a general number, and there is no way to collocate cookbooks about African American cooking or soul food. Soul food is closely related to southern cooking, so it could be classed at TX715.2.S68 for Southern style cooking. Because soul food is not a separate subject heading, it cannot be used on bibliographic records, and thus, cannot be classed with other southern cookbooks.

Mexican American cooking (Tex-Mex cooking). "Mexican American cooking" is classed with Southwestern style cooking at TX715.2.S69. This number does not represent the heading well. It may be classed here because of the "Tex-Mex cooking" reference. A problem is differentiating Mexican American cooking and Mexican cooking. National ethnic groups in the United States are supposed to be classed under the number for the nation, but a Mexican American cookbook would not be classed with Mexican cooking at TX716.M4. Instead, it would be classed with Southwestern style cooking at TX715.2.S69.

Indian cooking. Indian cookbooks are classed at TX715, the general number for American cooking. "Indian cooking" covers Native Americans in the Western Hemisphere, so classifying these cookbooks under the general American cooking number is not appropriate.

\section{Suggestions}

This research reveals many areas that should be addressed in both the subject headings and classification numbers for cooking. The suggestions made here are small changes that could help the standards be more permeable and could help library users find soul food, Tex-Mex, and Native American cookbooks.

LCSH: Cooking, Soul food. "Cooking, Soul food" (or Cooking, Soul food style) should be a separate subject heading with a see also reference (related term) to and from "Cooking, American - Southern style and "Cooking, African American." Soul food is an expression but it has become synonymous with African American southern cooking. This would reflect the cuisine more accurately and would allow the 
subject headings to be related in a nonhierarchical way. In addition, the heading "African American cooking" should be flipped back to "Cooking, African American" so it is not excluded from other national and ethnic cuisines. See Table 3.

Table 3. Suggested subject headings for Cooking, Soul food and African American cooking

\begin{tabular}{|l|l|l|}
\hline \multicolumn{1}{|c|}{$\begin{array}{c}\text { Current Heading } \\
\text { African American cooking }\end{array}$} & $\begin{array}{c}\text { Suggested Heading 1 } \\
\text { Cooking, African American }\end{array}$ & \multicolumn{1}{|c|}{$\begin{array}{c}\text { Suggested Heading 2 } \\
\text { Cooking, Soul food }\end{array}$} \\
\hline UF African American cookery & UF African American cooking & UF Soul food cooking \\
\hline UF Afro-American cookery & UF African American cookery & RT Cooking, African American \\
\hline UF Cookery, Afro-American & UF Afro-American cookery & $\begin{array}{l}\text { RT Cooking, American - } \\
\text { Southern style }\end{array}$ \\
\hline UF Cookery, Negro & UF Cookery, Afro-American & BT Cooking, American \\
\hline UF Soul food cooking & UF Cookery, Negro & \\
\hline BT Cooking, American & RT Cooking, Soul food & \\
\hline
\end{tabular}

LCSH: Cooking, Tex-Mex. "Cooking, Tex-Mex" (or, Cooking, Tex-Mex style) should be added with a see also reference (related term) to and from "Cooking, American - Southwestern style," "Cooking, Mexican," "Cooking - Texas," and "Cooking - New Mexico." This would reflect Tex-Mex cooking more accurately, and allow the subject headings to be related in a nonhierarchical way. To be consistent with the treatment of other cookbooks about national ethnic groups in the United States, "Mexican American cooking" should be canceled as a main heading and added as a reference to "Cooking, Mexican." See Table 4.

Table 4. Suggested subject headings for Tex-Mex and Mexican American cooking

\begin{tabular}{|l|l|l|}
\hline \multicolumn{1}{|c|}{$\begin{array}{c}\text { Current Heading } \\
\text { Mexican American cooking }\end{array}$} & \multicolumn{1}{|c|}{$\begin{array}{c}\text { Suggested Heading } \\
\text { Cooking, Tex-Mex }\end{array}$} & \multicolumn{1}{c|}{$\begin{array}{c}\text { Current Heading with } \\
\text { Suggestions } \\
\text { Cooking, Mexican }\end{array}$} \\
\hline & UF Tex-Mex cooking & UF Cookery, Mexican \\
\hline $\begin{array}{l}\text { UF Cookery, Mexican } \\
\text { American }\end{array}$ & RT Cooking, Mexican & UF: Mexican cooking \\
\hline UF Cooking, Tex-Mex & $\begin{array}{l}\text { RT Cooking, American - } \\
\text { Southwestern style }\end{array}$ & UF: Mexican American cooking \\
\hline UF Mexican American cookery & RT Cooking -- Texas & UF: Cooking, Mexican American \\
\hline UF Tex-Mex cooking & RT Cooking - New Mexico & RT: Cooking, Tex-Mex \\
\hline BT Cooking, American & BT Cooking, American & \\
\hline
\end{tabular}

LCSH: Indian cooking. The subject heading should be changed to "Cooking, Native American." LC has already established "Indians" to describe Native Americans in the Western Hemisphere, but "Cooking, Native American" also would cover Native Americans in the Western Hemisphere, and it would be more culturally sensitive. This heading would not cause confusion for catalogers. "Indian cooking" should be added as a reference to "Cooking, Native American," and "East Indian cooking" should be added as a reference to "Cooking, Indic." This would explain the meaning of each subject heading. See Table 5.

Table 5. Suggested subject headings for Native American cooking

\begin{tabular}{|c|c|c|}
\hline $\begin{array}{c}\text { Current heading } \\
\text { Indian cooking }\end{array}$ & $\begin{array}{c}\text { Suggested heading } \\
\text { Cooking, Native American }\end{array}$ & $\begin{array}{c}\text { Current heading with } \\
\text { suggestions } \\
\text { Cooking, Indic }\end{array}$ \\
\hline
\end{tabular}




\begin{tabular}{|l|l|l|}
\hline UF Cookery, Indian & UF: Native American cooking & UF: Cookery, Indic \\
\hline UF Indian cookery & UF: Indian cooking & UF: Indic cooking \\
\hline BT Cooking & UF Indian cookery & UF: East Indian cooking \\
\hline & UF Cooking, Indian & UF: Cooking, East Indian \\
\hline & UF: Cookery, Indian & \\
\hline
\end{tabular}

LCC: Soul food. Following the suggestions for the subject headings, cookbooks on African American cooking and Soul Food cooking should be pulled out of the general American cooking number at TX715. Because the subject headings are closely related, they should be classed at the same number under "By style of cooking, A-Z," which should be expanded to include different ethnic groups. Perhaps, the number could be: TX715.2.S65: Soul food (and African American). This would bring together all African American and soul food cookbooks at one number and make them easier to find. See Table 6.

LCC: Tex-Mex. Mexican American cooking is currently classed under "Cooking, American -- Southwestern style" at TX715.2.S69. Although this is partly correct, it does not account for Mexican American cooking that happens in other parts of the United States, and it is treated as an exception to the practice of classifying national ethnic groups in the United States with the nation. Instead, Tex-Mex cooking should have its own classification number under "By style of cooking, A-Z," perhaps TX715.2.T49. Cookbooks about Mexican American cuisine should be classified with other Mexican cookbooks at TX716.M4. See Table 6.

LCC: Native American. Native American cookbooks are classified under the general American cooking number at TX715, so these cookbooks should be pulled out of that classification number. Unless more room is made in the subclass, however, there is no good place to class these cookbooks. They should be classified before America, but TX714 is already taken by general recipe collections. A suggestion is TX715.9. That classes Native American cookbooks under American cooking, unfortunately, but it pulls those cookbooks out of the general TX715 number and places them after Greenlandic cooking but before Latin American cooking. See Table 6.

Table 6. Suggested classification numbers

\begin{tabular}{|l|l|}
\hline \multicolumn{1}{|c|}{ Current Schedule - American cooking } & \multicolumn{1}{c|}{ Suggested Schedule - American cooking } \\
\hline TX715: General Works & TX715: General Works \\
\hline TX715.2A-Z: By Style of cooking, A-Z & TX715.2A-Z: By Style of cooking, A-Z \\
\hline TX715.2.C34: California style & TX715.2.C34: California style \\
\hline TX715.2.L68: Louisiana style & TX715.2.L68: Louisiana style \\
\hline TX715.2.M53: Midwestern style & TX715.2.M53: Midwestern style \\
\hline TX715.2.N48: New England style & TX715.2.N48: New England style \\
\hline TX715.2.P32: Pacific Northwest style & TX715.2.P32: Pacific Northwest style \\
\hline & TX715.2.S65: Soul food (and African American) \\
\hline TX715.2.S68: Southern Style & TX715.2.S68: Southern Style \\
\hline TX715.2.S69: Southwestern style & TX715.2.S69: Southwestern style \\
\hline & TX715.2.T49: Tex-Mex \\
\hline TX715.2.W47: Western style & TX715.2.W47: Western style \\
\hline TX715.6: Canadian & TX715.6: Canadian \\
\hline TX715.8: Greenlandic & TX715.8: Greenlandic \\
\hline & TX715.9: Native American \\
\hline TX716: Latin American & TX716: Latin American \\
\hline
\end{tabular}




\section{Future research}

Small suggestions were made that could make each standard more permeable without disrupting the overall structure of each standard. This research project also has uncovered many areas of future research. Much work should be done to determine if the structure of the standards reflect the subject of cooking today.

Subject headings for national and ethnic cuisines. One area of future research is the subject headings for national and ethnic cuisines, especially American cooking. American cooking is a blend of different national, ethnic, and regional cuisines, and there are distinct Americanized versions of national cuisines. For example, there are many Italian-American cookbooks, but they are assigned the subject heading "Cooking, Italian." Is this appropriate? Should there be a separate subject heading for "Cooking, Italian American" or should it be added as a cross reference to "Cooking, Italian"? More research is needed to provide adequate and robust subject access for national and ethnic groups in the United States.

The TX subclass. Another area of research is the TX subclass, which should be revised to better reflect cookbooks, cooking, and food. Few numbers are used in this subclass, so the subclass should be spread out to organize and represent the subject of cooking better. Numbers assigned to specific national and ethnic cuisines should be revised and expanded so every nation is represented in the classification. In addition, future research should look at the nascent area of food studies to determine if it warrants a separate area in the classification.

Cookbooks for diets and diseases. A final area of future research concerns cookbooks for diets and diseases. Are they classed appropriately? There are thousands of weight loss and low-fat cookbooks, but many do not take a medical viewpoint, nor are they written by medical professionals. LC $(2009,2)$ explains that books of recipes about a specific diet are not considered "cookbooks per se." This leads, perhaps, to the most important question of all: If a book of recipes is not a cookbook, then what is a cookbook?

\section{Conclusion}

This research project examined how cookbooks are treated in the Library of Congress Subject Headings and the Library of Congress Classification. Each edition of each standard was studied to understand how cooking subject headings and classification numbers have changed over time. The research reveals that each standard has kept the same overall structure since in the early 20th century. Three specific cooking subject headings/classification numbers were examined: African American cooking/Soul food cooking, Mexican American cooking/Tex-Mex cooking, and Indian cooking. They are problematic because they do not fall neatly into the structure of the standards. Some small suggestions were made to make each standard more permeable and to help library users find cookbooks on these topics. However, the cooking area of each standard should be revised to be more dynamic and robust. A better structured LCSH and LCC that reflects food and cooking today, that is permeable, and that makes room for future changes and new topics, would help users find materials on food and cooking in libraries. 


\section{Acknowledgement}

I would like to thank the staff at the Texas Woman's University Library and University of North Texas Library who helped me gather the data I needed to do this project.

\section{References}

Berman, S. 1971. Prejudices and antipathies: A tract on the LC subject heads concerning people. Jefferson, NC: McFarland \& Co.

Berman, S. 1981. The joy of cataloging: Essays, letters, and other explosions. Phoenix: Oryx Press.

Berman, S. June 2000. Finding material on "those people" (and their concerns) in library catalogs. Multicultural Review, 26-28, 48-52.

Chan, L. M. 1999. A guide to the Library of Congress Classification. 5th ed. Englewood, CO: Libraries Unlimited.

Chan. L. M. 2005. Library of Congress Subject Headings: Principles and application. 4th ed. Westport, CT: Libraries Unlimited.

Christensen. B. 2008. Minoritization vs. universalization: Lesbianism and male homosexuality in LCSH and LCC. Knowledge Organization 35: 229-38.

Classification Web, http://classificationweb.net/ (accessed May 4, 2013).

Drabinski, E. 2013. Queering the catalog: Queer theory and the politics of correction. Library Quarterly 83: 94-111.

Fina, M. 1993. The role of subject headings in access to information: The experience of one Spanish-speaking patron. Cataloging \& Classification Quarterly 17: 267-74.

Julien, C., P. Tirilly, J. Leide, C. Guastavino. 2012. Constructing a true LCSH tree of a science and engineering collection. Journal of the American Society for Information Science \& Technology 63: 2405-2418.

Knowlton, S. A. 2005. Three decades since Prejudices and antipathies: A study of changes in the Library of Congress Subject Headings. Cataloging \& Classification Quarterly 40: 12344.

Library of Congress. 1910-2010. Library of Congress Classification. Class R: Medicine. Washington, D.C.: U.S. Government Printing Office.

Library of Congress. 1910-2010. Library of Congress Classification. Class T: Technology. Washington, D.C.: U.S. Government Printing Office.

Library of Congress. 1975-2012. Library of Congress subject headings. 8th ed.-34th ed. Washington, D.C.: U.S. Government Printing Office.

Library of Congress. 1910/14-1966. Subject headings used in the dictionary catalogs of the

Library of Congress. 1st ed.-7th ed. Washington, D.C.: U.S. Government Printing Office.

Library of Congress. 2009. Revision of headings for cooking and cookbooks. http://www.loc.gov/catdir/cpso/cooking.pdf (Accessed May 4, 2013).

Library of Congress authorities, http://authorities.loc.gov/ (accessed May 4, 2013).

Library of Congress online catalog, http://catalog.loc.gov/ (accessed May 4, 2013).

Marshall, J. 1972. LC labeling: An indictment. In Revolting librarians, ed. C. West and E. Katz, San Francisco: Booklegger, pp. 45-49.

Olson, H. A. 1998. Mapping beyond Dewey's boundaries: Constructing classificatory space for marginalized knowledge domains. Library Trends 47: 233-54.

Olson, H. A. 2000. Difference, culture and change: The untapped potential of LCSH. Cataloging \& Classification Quarterly 29: 53-71.

Olson, H. A. 2001a. The power to name: Representation in library catalogs. Signs: Journal of Women in Culture and Society 26: 639-68.

Olson, H. A. 2001b. Sameness and difference: A cultural foundation of classification. Library Resources \& Technical Services 45: 115-22. 
Hoffman, G. (2013). How are Cookbooks Classified in Libraries? An Examination of LCSH and LCC. NASKO, 4(1).

Retrieved from http://journals.lib.washington.edu/index.php/nasko/article/view/14650

Olson, H. A. 2002. The power to name: Locating the limits of subject representation in libraries. Dordrecht: Kluwer Academic Publishers.

Olson, H. A. 2004. The ubiquitous hierarchy: An army to overcome the threat of a mob. Library Trends 52: 604-616.

Olson, H. A. 2007. How we construct subjects: A feminist analysis. Library Trends 56: 509-41. The Oxford encyclopedia of food and drink in America. 2005. Oxford: Oxford University Press. Subject Headings Manual. 2008. Washington, D.C.: U.S. Government Printing Office. 